\title{
Pengaruh Laju Pergantian Air Terhadap Perkembangan dan Kelangsungan Hidup Larva Kerang Mutiara (Pinctada maxima) pada Skala Laboratorium
}

\author{
[Effect of Water Exchange Rate on the Development and Survival Rate of Pearl \\ Oyster (Pinctada maxima) Larvae in Laboratory Scale]
}

\author{
Azuka B. Yuukanna ${ }^{1}$, Abdul Rahman ${ }^{1}$, Abdul M. Balubi'`Agus Kurnia ${ }^{1}$ \\ ${ }^{1}$ Program Studi Budidaya Perairan, Faluktas Perikanan dan Ilmu Kelautan Universitas Halu Oleo \\ Jl. HAE Mokodompit Kampus Bumi Tridharma Anduonohu Kendari, Indonesia 93232 \\ Email korespondensi : azukayuukanna@gmail.com
}

\begin{abstract}
ABSTRAK
Penelitian ini bertujuan untuk mengetahui laju pergantian air yang optimal pada sistem sirkulasi air terhadap perkembangan dan kelangsungan hidup larva kerang mutiara ( $P$. maxima) yang dipelihara pada skala laboratorium. Penelitian didesain dengan metode rancangan acak lengkap yang terdiri atas empat perlakuan dengan tiga ulangan, yaitu : K (kontrol), A (200 $\mathrm{ml} /$ menit), B (400 ml/menit), dan C (600 ml/menit). Hewan uji larva $P$. maxima stadia D-veliger ukuran $90 \mu \mathrm{m} \times 70 \mu \mathrm{m}$, yang dipelihara selama 45 hari dengan kepadatan 2000 larva per wadah pemeliharaan. Parameter yang diukur antara lain: tingkat kelangsungan hidup, pertumbuhan mutlak, laju pertumbuhan spesifik, kecepatan metamorfosis stadia, dan parameter kualitas air. Hasil penelitian menunjukan bahwa tingkat kelangsungan hidup tertinggi diperoleh pada perlakuan $600 \mathrm{ml} / \mathrm{menit}$ yaitu $11,83 \% \pm 0,20$. Pertumbuhan mutlak AP dan DV tertinggi pada perlakuan $600 \mathrm{ml} / \mathrm{menit}$ dengan perolehan masing-masing hasil yaitu $1565 \mu \mathrm{m} \pm 23,35$ dan $1199 \mu \mathrm{m} \pm 28,10$. Hasil laju pertumbuhan spesifik AP dan DV tertinggi diperoleh perlakuan $600 \mathrm{ml} /$ menit yaitu $6,93 \% \pm 0,03$ dan $6,90 \% \pm 0,05$. Kecepatan perkembangan stadia dari stadia D-veliger - Pediveliger tercepat, diperoleh perlakuan $200 \mathrm{ml} /$ menit, dengan perolehan waktu metamorfosis 24 hari 21 jam. Hasil ANOVA menunjukan bahwa tidak ada pengaruh nyata untuk setiap parameter yang diukur. Penelitian ini menyimpulkan bahwa laju pergantian air sebesar 200-600 ml/menit dapat meningkatkan perkembangan dan kelangsungan hidup larva kerang mutiara (P. maxima) yang dipelihara pada skala laboratorium.
\end{abstract}

Kata Kunci : perkembangan larva kerang mutiara, laju pergantian air, P. maxima

\begin{abstract}
The objective of this research was to determine optimum of water exchange rate in water circulation system for the development and survival rate of pearl oyster larvae (P. Maxima) under reared in laboratory scale. This research was designed by using completely randomized design method (CRD) with four different treatments and three replications, they were C (control), A (200 ml / $\mathrm{min})$, B (400 $\mathrm{ml} / \mathrm{min})$, and C (600 ml / min). This research used larvae P. maxima stadia Dveliger size $90 \mu \mathrm{m} \times 70 \mu \mathrm{m}$, which reared for 45 days with a density of 2000 larvae per container. Parameters measured include: survival rate $(\%)$, weight gain $(\mu \mathrm{m})$, specific growth rate $(\%)$, and speed of metamorphosis (day). The results showed that the highest of survival rate of larvae was obtained by treatment of $600 \mathrm{ml} / \mathrm{min}$ with $11.83 \% \pm 0.20$. The highest of weight gain of AP (anterior - posterior) and DV (dorsal - ventral) were obtained by treatment of $600 \mathrm{ml} / \mathrm{min}$ with values of $1565 \mu \mathrm{m} \pm 23.35$ and $1199 \mu \mathrm{m} \pm 28.10$, rspectively. The highest of SGR of AP and DV were obtained by treatment of $600 \mathrm{ml} / \mathrm{min}$ with value of $6.93 \% \pm 0.03$ and $6.90 \% \pm 0.05$, respectively. The fastest speed of metamorphosis from D-veliger stage to Pediveliger stage, were obtained by treatment of $200 \mathrm{ml} / \mathrm{min}$, with average time was 24 days 21 hours. ANOVA test results show that, all treatments of water exchange rate in larvae rearing were not significantly different in all parameters measured. In conclusion, water exchange rate in $200 \mathrm{ml} / \mathrm{min}-600 \mathrm{ml} / \mathrm{min}$ could improve the development stage and survival rate of pearl oyster (P.maxima) larvae under reared in laboratory scale.
\end{abstract}

Keywords: Larvae development of Pearl Oyster, water exchange rate, P. maxima

\section{PENDAHULUAN}

Kerang mutiara $P$. maxima adalah spesies kerang yang menghasilkan mutiara terbaik, juga dikenal sebagai Mutiara Laut Selatan (south sea pearl). Kerang mutiara $P$. maxima memiliki nilai ekonomis tinggi dan sudah lama dibudidayakan untuk agroindustri mutiara di Indonesia(Septy,2018). Permintaan pasar yang meningkat mengakibatkan semakin banyaknya individu kerang $P$. maxima yang dibutuhkan untuk menghasilkan mutiara (Zulendra, 2012 dalam Tomatala, 2014). Secara tradisional, mutiara hanya diperoleh dari alam, tetapi karena kemajuan ilmiah, sebagian besar kerang mutiara saat ini dapat diproduksi dari pembenihan kerang mutiara (Septy, 2018).

Teknologi pembenihan kerang mutiara pada mulanya terkesan "rahasia" karena hanya dikuasai oleh teknisi teknisi asing yang 
kebanyakan dari Jepang bekerja di hatchery (tempat pembenihan). Kerang mutiara juga masih terbatas pada perusahaan besar yang kebanyakan PMA (Penanam Modal Asing). Menjelang tahun 2000, berkembanglah hatchery yang dimiliki oleh pengusaha lokal dan dikerjakan oleh tenaga domestik akan tetapi berbagai teknologi pembenihan hatchery masih belum dikuasai perusahaan lokal (Sujoko, 2010). Menurut Sudewi et al. (2016), salah satu masalah yang dihadapi dalam pembenihan kerang mutiara adalah rendahnya sintasan larva. Salah satu solusi yang dapat mengatasi kendala tersebut adalah pemeliharaan larva dengan aplikasi sirkulasi pergantian air dalam wadah pemeliharaan dengan pemberian laju pergantian air yang konstan.

Kelebihan dari sirkulasi air adalah dapat membantu distribusi oksigen ke segala arah dan dapat menjaga akumulasi atau mengumpulnya hasil metabolisme atau sisa-sisa pakan yang beracun sehingga kadar atau daya racunnya dapat dikurangi (Kelabora dan Sabariah, 2010). Efektifitas sistem sirkulasi dalam memperbaiki kualitas air media budidaya salah satunya tergantung pada laju pergantian air. Semakin tinggi laju pergantian air yang dihasilkan maka kekuatan pergerakan massa air yang dihasilkan juga tinggi dan kandungan oksigen serta sarana pengeluaran limbah hasil metabolisme meningkat (Zonneveld et al., 1991).

Pergerakan air menyebabkan adanya distribusi oksigen yang merata, selain itu, mampu menyuplai pakan alami secara merata sehingga penyebaran pakan alami menjadi lebih merata dan tidak berkumpul di satu titik. Selain itu, dengan adanya pergerakan air, maka zat sisa metabolisme akan terbawa sehingga akan memperbaiki kualitas perairan (Kelabora dan Sabariah 2010). Selain itu berdasarkan penelitian Indrayana et al. (2014), pergerakan air memberi pengaruh terhadap sebaran dari parameter-parameter kualitas air. Pengamatan lapangan $P$. maxima dan $P$. Margaritifera di Hawaii menyarankan bahwa arus kuat dapat meningkatkan laju pertumbuhan (Galtsoff, 1933 dalam Southgate dan Lucas, 2008). Namun, kajian mengenai laju pergantian air yang optimal terhadap pertumbuhan dan kelangsungan hidup larva kerang mutiara $(P$. maxima) yang dipelihara pada skala laboratorium dalam sistem resirkulasi belum diketahui. Oleh karena itu, penelitian ini perlu dilaksanakan agar dapat mengetahui kisaran laju pergantian air yang optimum bagi pemeliharaan larva kerang mutiara ( $P$. maxima) pada skala laboratorium dalam sistem sirkulasi.

\section{BAHAN DAN METODE}

\section{Persiapan Hewan Uji}

Hewan uji yang digunakan adalah larva dari pemijahan induk kerang mutiara $(P$. maxima) dengan perbandingan 10 induk jantan dan 20 induk betina. Seleksi benih dilakukan dengan menggunakan plankton net dengan ukuran mata $100 \mu \mathrm{m}, 80 \mu \mathrm{m}, 60 \mu \mathrm{m}$, dan $45 \mu \mathrm{m}$. Saringan ini disusun berdasarkan besaran ukuran mata yaitu ukuran yang besar di bagian atas dan disusul ukuran berikutnya. Ukuran mata menunjukkan satuan besaran pertumbuhan larva yang tidak tersaring pada setiap ukuran mata plankton net. Ukuran larva stadia Dveliger diketahui berdasarkan larva tidak yang tersaring pada plankton net ukuran $80 \mu \mathrm{m}$. Penebaran larva pada wadah penelitian dilakukan dengan sistem volumetri yaitu dengan mengambil larva D-veliger dari bak penampungan dalam volume tertentu yang telah diketahui kepadatannya. Penghitungan kepadatan larva dalam bak penampungan dilakukan dengan metode sampling. Kepadatan hewan uji setiap wadah pemeliharaan sebanyak 2000 larva.

\section{Persiapan Wadah}

Wadah penelitian berupa wadah plastik yang berbentuk persegi panjang dengan ukuran dimensi $50 \times 20 \times 35 \mathrm{~cm}^{3}$ dilengkapi dengan aerasi, yang disusun dengan sistem sirkulasi. Sirkulasi media yang didesain menggunakan pompa air dan pipa distribusi (PVC) berdiameter $1 / 2$ " dan plankton net ukuran $25 \mu \mathrm{m}$ di saluran pengeluaran air untuk tetap menjaga hewan uji berada di wadah pemeliharaan. Pengaturan laju pergantian air $200 \mathrm{ml} /$ menit, $400 \mathrm{ml} / \mathrm{menit}$ dan $600 \mathrm{ml} / \mathrm{menit}$ diatur dengan keran air yang terpasang pada pipa distribusi. Kolektor yang digunakan adalah paranet tali rafia dengan kerapatan $85 \%$ yang memiliki ukuran $25 \times 35$ sebanyak 3 lembar per wadah penelitian. Banyaknya wadah yang digunakan sebanyak 12 wadah.

\section{Sistem Pemberian Pakan}

Pakan diperoleh dari hasil budidaya di Laboratorium UD. Bintang Laut, Parepare, Sulawesi Selatan. Pemberian pakan dilakukan 2 
kali sehari, pada pagi (07.00 WITA) dan sore (16.00 WITA). Komposisi phytoplankton yang diberikan terdiri dari campuran Pavlova lutheri (25\%), Chaetoceros amami (25\%), Chaetoceros muelleri (25\%), dan Chaetoceros gracilis (25\%). Pakan alami diberikan saat sudah berumur 4 hari dengan kepadatan berkisar $4 \times 10^{6} \mathrm{sel} / \mathrm{ml}$. Jumlah pakan berbeda setiap perkembangan stadi larva. Stadia Dveliger diberikan pakan dengan jumlah volume total sebesar $80 \mathrm{ml}$; stadia Umbo-Veliger diberikan pakan campuran dengan jumlah volume total sebesar $100 \mathrm{ml}$; stadia Eyespot diberikan pakan campuran dengan jumlah volume total sebesar $200 \mathrm{ml}$; stadia Pediveliger diberi pakan campuran dengan jumlah volume total sebesar $300 \mathrm{ml}$; dan stadia Spat diberi pakan campuran dengan jumlah volume total sebesar $400 \mathrm{ml}$.

\section{Rancangan Percobaan}

Penelitian ini menggunakan Rancangan Acak Lengkap (RAL) dengan 4 perlakuan dan 3 ulangan. Adapun perlakuan yang diuji antara lain: perlakuan K (Kontrol), Perlakuan A (laju pergantian air $200 \mathrm{ml} / \mathrm{menit}$ ), Perlakuan B (laju pergantian air $400 \mathrm{ml} / \mathrm{menit}$ ), dan Perlakuan C ( laju pergantian air $600 \mathrm{ml} / \mathrm{menit}$ ).

\section{Variabel yang diamati}

\section{Kelangsungan Hidup (SR)}

Kelangsungan hidup larva atau anakan kerang dihitung dengan menggunakan rumus dalam Zonneveld et al. (1991) yaitu :

$$
\mathrm{SR}=\left(\mathrm{N}_{1} / \mathrm{N}_{0}\right) \times 100 \%
$$

Dengan : $\mathrm{N}_{1}=$ jumlah individu pada akhir penelitian (ekor), $\mathrm{N}_{0}=$ Jumlah individu pada awal penelitian (ekor).

\section{Pertumbuhan Mutlak}

Pertumbuhan mutlak larva atau anakan kerang dihitung dengan menggunakan rumus dalam Bhujel (2008) yaitu :

$$
\mathrm{PM}=\mathrm{L}_{1}-\mathrm{L}_{0}
$$

Dengan : PM $=$ Pertumbuhan mutlak $(\mu \mathrm{m}), \mathrm{L}_{1}=$ Panjang larva pada akhir pengamatan $(\mu \mathrm{m}), \mathrm{L}_{0}=$ Panjang larva pada awal pengamatan $(\mu \mathrm{m})$.

\section{Laju Pertumbuhan Spesifik}

Laju pertumbuhan spesifik larva atau anakan kerang dihitung dengan menggunakan rumus dalam Bhujel (2008) yaitu :

$$
\text { LPS }=\left(100\left(\operatorname{LnL}_{1}-\mathrm{LnL}_{0}\right)\right) / \mathrm{T}
$$

Dengan : LPS $=$ Laju Pertumbuhan Spesifik (\%), $\mathrm{L}_{1}=$ Panjang larva pada akhir pengamatan $(\mu \mathrm{m})$, $\mathrm{L}_{0}=$ Panjang larva pada awal pengamatan $(\mu \mathrm{m}), \quad \mathrm{Ln}=$ Logaritma natural, $\mathrm{T}=$ Waktu Pemeliharaan (Hari).

\section{Kecepatan Perkembangan Stadia}

Kecepatan perkembangan stadia diidentifikasi dengan melihat perubahan pada larva. Perkembangan larva yang diidentifikasi berupa kecepatan waktu metamorfosis. Kecepatan metamorfosis dihitung berdasarkan lama waktu larva berkembang dalam setiap stadia. Pengamatan dilakukan sedikitnya setiap enam jam sekali, dengan minimal persentase sebesar $60 \%$ dari sampel hewan uji yang sudah bermetamorfosis.

\section{Parameter Kualitas Air}

Parameter kualitas air yang diamati selama penelitian meliputi suhu, salinitas, dan derajat keasaman. Parameter kualitas air tersebut diukur sehari sekali selama jangka waktu penelitian berlangsung.

\section{HASIL}

\section{Kelangsungan Hidup (SR)}

Hasil tingkat kelangsungan hidup larva kerang ( $P$. maxima) yang diperoleh menunjukan bahwa nilai tingkat kelangsungan hidup tertinggi didapatkan pada perlakuan 600 $\mathrm{ml} /$ menit $(11,83 \% \pm 0,20)$ dan terendah pada perlakuan $400 \mathrm{ml} / \mathrm{menit}(11,15 \% \pm 0,27)$ (Gambar 1). Berdasarkan hasil analisis ragam menunjukan bahwa perlakuan yang diuji tidak memberikan pengaruh nyata terhadap kelangsungan hidup larva kerang mutiara $(P$. maxima).

\section{Pertumbuhan Mutlak}

Hasil yang diperoleh menunjukan bahwa pertumbuhan mutlak bagian anterior-posterior tertinggi didapatkan pada perlakuan 600 $\mathrm{ml} /$ menit $(1565 \mu \mathrm{m} \pm 23,35)$ dan terendah pada perlakuan $400 \mathrm{ml} /$ menit $(1531 \mu \mathrm{m} \pm 20,13)$ (Gambar 2). Berdasarkan hasil analisi ragam menunjukan bahwa perlakuan memberikan hasil yang tidak berbeda nyata.

Hasil yang diperoleh menunjukan bahwa pertumbuhan mutlak bagian dorsal-ventral tertinggi didapatkan pada perlakuan 600 $\mathrm{ml} /$ menit $(1199 \mu \mathrm{m} \pm 28,10)$ dan terendah pada perlakuan $400 \mathrm{ml} /$ menit $(1189 \mu \mathrm{m} \pm 20,53)$. 
Berdasarkan hasil analisis ragam, menunjukan bahwa perlakuan tidak memberi pengaruh nyata terhadap pertumbuhan mutlak bagian dorsalventral.

\section{Laju pertumbuhan spesifik}

Hasil laju pertumbuhan spesifik yang diperoleh dapat dilihat dalam bentuk grafik sebagaimana pada Tabel 1 untuk laju pertumbuhan spesifik Anterior-Posterior dan Tabel 2 untuk laju pertumbuhan spesifik bagian Dorsal-Ventral. Berdasarkan hasil analisis ragam perlakuan yang diuji pada larva kerang mutiara $(P$. maxima) tidak memberikan pengaruh nyata terhadap laju pertumbuhan spesifik bagian anterior-posterior dan laju pertumbuhan spesifik bagian dorsal-ventral.

\section{Perkembangan stadia}

Hasil pertumbuhan ukuran hewan uji pada awal kemunculan setiap stadia selama penelitian disajikan pada Tabel 3, dan hasil kecepatan metamofosis hewan uji disajikan pada Tabel 4.

Hasil yang diperoleh menunjukan bahwa Perlakuan $200 \mathrm{ml} /$ menit memberikan waktu tempuh rata-rata tercepat dengan perolehan waktu 24 hari 21 jam dan perlakuan 600 $\mathrm{ml} /$ menit memberikan waktu tempuh rata-rata terlama dengan perolehan waktu 25 hari 9 jam. Berdasarkan hasil analisis uji ragam (ANOVA) menunjukan bahwa perlakuan dalam penelitian ini tidak memberikan pengaruh yang nyata terhadap kecepatan perkembangan stadia ratarata larva kerang mutiara ( $P$. maxima) dari stadia D-veliger sampai stadia pediveliger.

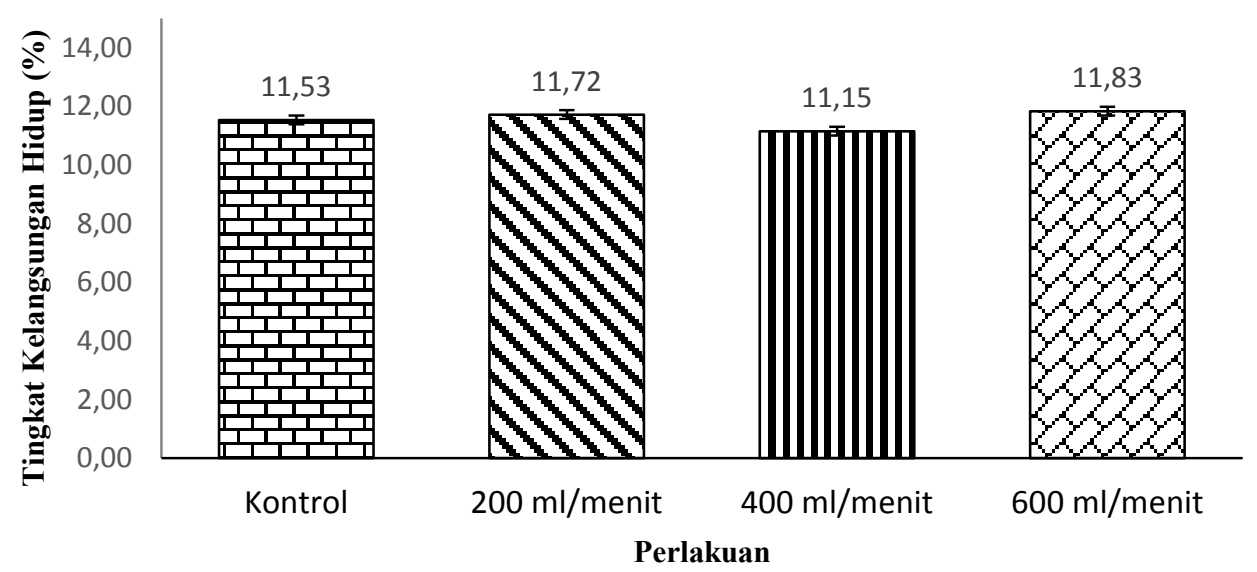

Gambar 1. Grafik Hasil Tingkat Kelangsungan Hidup Larva Kerang (P. maxima) terhadap Laju Pergantian Air yang Berbeda

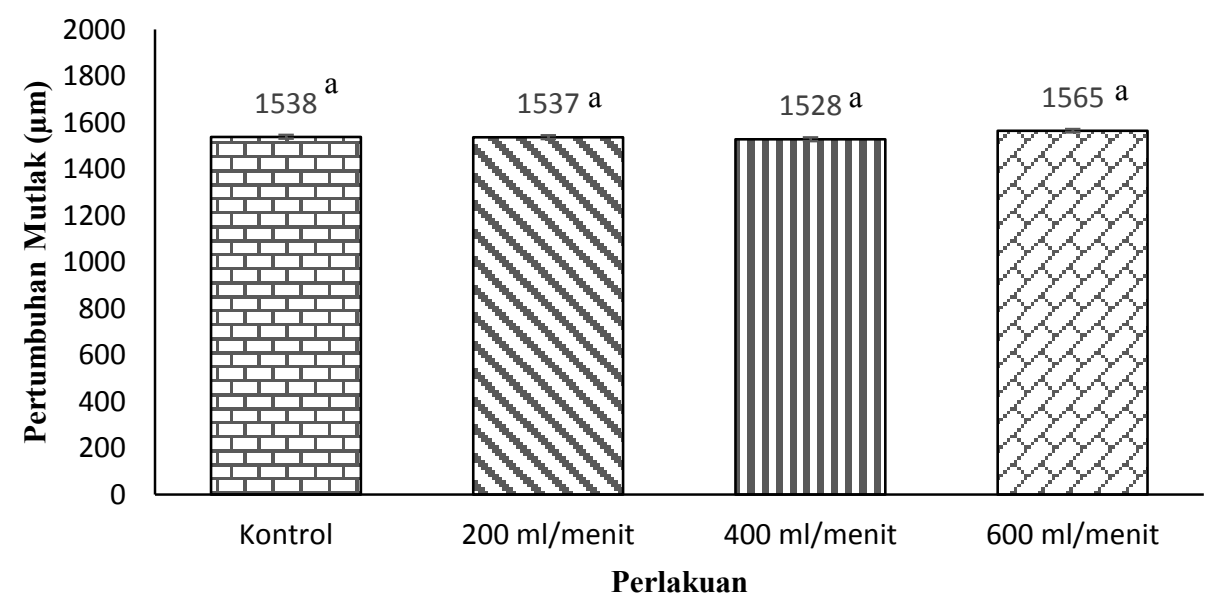

Gambar 2. Grafik Hasil Pertumbuhan Mutlak Anterior-Posterior Larva Kerang Mutiara (P.maxima) pada Laju Pergantian air yang berbeda, ${ }^{\text {a }}$ superscript yang sama menunjukkan tidak ada perbedaan signifikan pada taraf $\alpha=0,05$. 


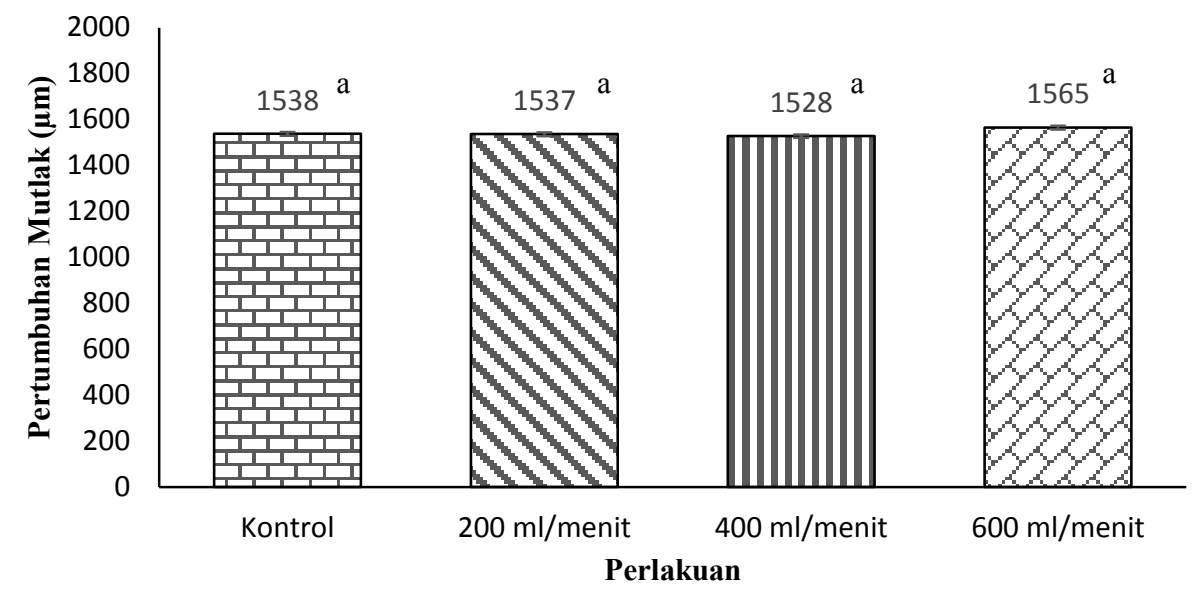

Gambar 3. Grafik Hasil Pertumbuhan Mutlak Dorsal - Ventral Larva Kerang Mutiara (P.maxima) pada Laju Pergantian air yang berbeda, ${ }^{a}$ superscript yang sama menunjukkan tidak ada perbedaan signifikan pada taraf $\alpha=0,05$.

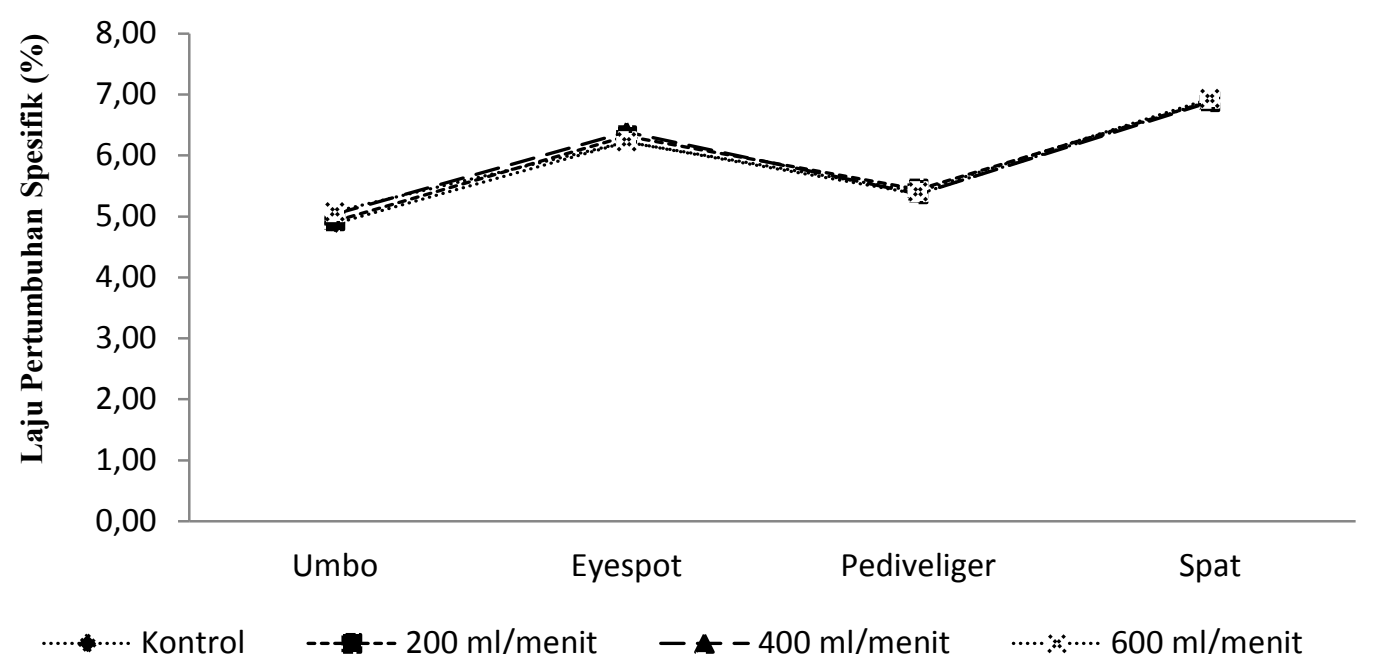

Gambar 4. Grafik Hasil Laju Pertumbuhan Spesifik Anterior-Posterior larva Kerang Mutiara (P.maxima) pada Laju Pergantian air yang berbeda

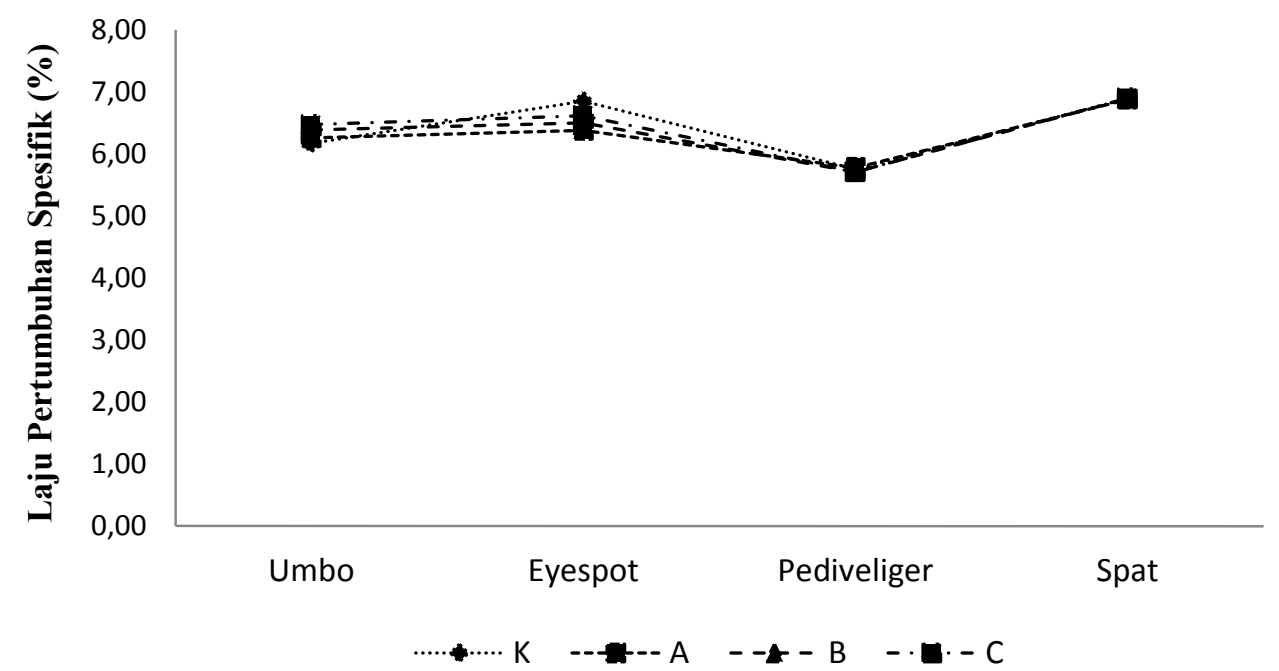

Gambar 5. Grafik Hasil Laju Pertumbuhan Spesifik Dorsal-Ventral larva Kerang Mutiara (P.maxima) pada Laju Pergantian air yang berbeda 
Tabel 1. Hasil Laju Pertumbuhan Spesifik Anterior - Posterior

\begin{tabular}{ccccc}
\hline \multirow{2}{*}{ Perlakuan } & \multicolumn{4}{c}{ Laju Pertumbuhan Spesifik (\%) } \\
\cline { 2 - 5 } & Umbo & Eyespot & Pediveliger & Spat \\
\hline Kontrol & 4,88 & 6,22 & 5,37 & 6,89 \\
$\mathbf{2 0 0} \mathbf{~ m l} /$ menit & 4,92 & 6,32 & 5,44 & 6,89 \\
$\mathbf{4 0 0} \mathbf{~ m l} /$ menit & 5,04 & 6,38 & 5,4 & 6,88 \\
$\mathbf{6 0 0} \mathbf{~ m l} /$ menit & 5,08 & 6,22 & 5,37 & 6,93 \\
\hline
\end{tabular}

Tabel 2. Hasil Laju Pertumbuhan Spesifik Dorsal - Ventral

\begin{tabular}{ccccc}
\hline \multirow{2}{*}{ Perlakuan } & \multicolumn{4}{c}{ Laju Pertumbuhan Spesifik (\%) } \\
\cline { 2 - 5 } & Umbo & Eyespot & Pediveliger & Spat \\
\hline Kontrol & 6,17 & 6,85 & 5,76 & 6,89 \\
$\mathbf{2 0 0} \mathbf{~ m l} /$ menit & 6,26 & 6,38 & 5,78 & 6,88 \\
$\mathbf{4 0 0} \mathbf{~ m l} /$ menit & 6,39 & 6,5 & 5,71 & 6,89 \\
$\mathbf{6 0 0} \mathbf{~ m l} /$ menit & 6,47 & 6,62 & 5,71 & 6,9 \\
\hline
\end{tabular}

Tabel 3. Ukuran Hewan Uji Larva (P. maxima) pada Setiap Awal Stadia

\begin{tabular}{|c|c|c|c|c|}
\hline \multirow{2}{*}{ No } & \multirow{2}{*}{ Stadia } & \multirow{2}{*}{ Perlakuan } & \multicolumn{2}{|c|}{ Ukuran $(\mu \mathrm{m})$} \\
\hline & & & $\mathbf{A P}$ & DV \\
\hline 1. & D-veliger & & 90 & 70 \\
\hline \multirow[t]{4}{*}{2.} & Umbo & $\mathrm{K}$ & $154 \pm 9,10$ & $138,00 \pm 12,65$ \\
\hline & & $\mathrm{A}$ & $154,67 \pm 9,90$ & $139,33 \pm 13,83$ \\
\hline & & $\mathrm{B}$ & $156,67 \pm 11,13$ & $141,33 \pm 9,15$ \\
\hline & & $\mathrm{C}$ & $157,33 \pm 9,61$ & $142,67 \pm 8,84$ \\
\hline \multirow[t]{4}{*}{3.} & Eye-Spot & $\mathrm{K}$ & $228,89 \pm 13,64$ & $188,89 \pm 19,00$ \\
\hline & & A & $232,22 \pm 13,94$ & $182,22 \pm 21,67$ \\
\hline & & $\mathrm{B}$ & $234,44 \pm 12,36$ & $185,56 \pm 18,10$ \\
\hline & & $\mathrm{C}$ & $228,89 \pm 14,53$ & $195,56 \pm 13,33$ \\
\hline \multirow[t]{4}{*}{4.} & Pediveliger & $\mathrm{K}$ & $277,78 \pm 8,33$ & $234,44 \pm 8,82$ \\
\hline & & A & $282,22 \pm 6,67$ & $235,56 \pm 7,26$ \\
\hline & & $\mathrm{B}$ & $277,78 \pm 10,93$ & $232,22 \pm 13,02$ \\
\hline & & $\mathrm{C}$ & $280,00 \pm 7,07$ & $232,22 \pm 8,33$ \\
\hline \multirow[t]{4}{*}{5.} & Spat & $\mathrm{K}$ & $1628,00 \pm 56,21$ & $1182,83 \pm 32,79$ \\
\hline & & A & $1516,45 \pm 42,33$ & $1259,33 \pm 49,20$ \\
\hline & & $\mathrm{B}$ & $1618,00 \pm 72,92$ & $1263,33 \pm 74,99$ \\
\hline & & $\mathrm{C}$ & $1654,67 \pm 101,06$ & $1269,33 \pm 68,29$ \\
\hline
\end{tabular}


Tabel 4. Hasil Perhitungan Waktu Metamorfosis Hewan Uji

\begin{tabular}{lllll}
\hline \multirow{2}{*}{ Metamorfosis Stadia } & \multicolumn{4}{c}{ Waktu Metamorfosis } \\
\cline { 2 - 5 } & Kontrol & $\mathbf{2 0 0} \mathbf{~ m l} / \mathbf{m e n i t}$ & $\mathbf{4 0 0} \mathbf{~ m l} / \mathbf{m e n i t}$ & $\mathbf{6 0 0} \mathbf{~ m l} / \mathbf{m e n i t}$ \\
\hline D-veliger - Umbo & 16 hari 20 jam & 15 hari 2 jam & 15 hari 12 jam & 15 hari 10 jam \\
Umbo - Eyespot & 3 hari 22 jam & 4 hari 23 jam & 3 hari 22 jam & 4 hari 14 jam \\
Eyespot - Pediveliger & 4 hari 10 jam & 4 hari 22 jam & 5 hari 12 jam & 5 hari 9 jam \\
\hline D-veliger - Pediveliger & 25 hari 2 jam & 24 hari 21 jam & 25 hari 22 jam & 25 hari 9 jam \\
\hline
\end{tabular}

\section{PEMBAHASAN}

\section{Kelangsungan Hidup (SR)}

Tingkat kelangsungan hidup larva kerang mutiara (P. maxima) pada penelitian ini sangat penting sebagai indikasi tingkat keberhasilan pemeliharaanhewan uji selama penelitian. Berdasarkan hasil yang diperoleh, tingkat kelangsungan hidup hewan uji memiliki persentase $>10 \%$ untuk semua perlakuan. Hasil persentase tingkat kelangsungan hidup pada penelitian ini lebih tinggi dibandingkan dengan penelitian Hamzah et al. (2016) dengan persentase tingkat kelangsungan hidup rata-rata sebesar 7,53 \% dengan kepadatan pemeliharaan 20.000 larva/80 liter air. Hasil dari analisis ragam (ANOVA) perlakuan laju pergantian air yang berbeda menunjukan hasil yang tidak nyata bagi kelangsungan hidup larva kerang mutiara $(P$. maxima $)$ dari stadia D-veliger sampai stadia spat yang dipelihara selama 45 hari. Manfaat dari pergerakan massa air diantaranya adalah untuk memperbaiki kualitas air, dimana dalam industri budidaya perikanan, penurunan kualitas air disebabkan oleh penumpukan sisa-sisa pakan buatan atau penumpukan senyawa-senyawa organik berupa jasad-jasad organisme akuatik (plankton) yang telah mati. Namun, pergerakan massa air pada penelitian ini tidak memberikan pengaruh terhadap kestabilan kualitas media pemeliharaan. Hal ini dikarenakan adanya pergantian air yang dilakukan untuk semua media uji setiap 4 hari selama penelitian.

Pergerakan menyebabkanadanya penyebaran oksigen terlarut yang merata (Kelabora dan Sabariah, 2010). Sebelum larva bermetamorfosis ke stadia spat, larva kerang mutiara ( $P$. maxima) berenang dan tersebar di kolom dan permuakaan air, sehingga dengan adanya pergerakan massa air dapat memberikan distribusi oksigen yang merata pada media pemeliharaan. Namun, pergerakan massa air pada penelitian ini tidak memberikan pengaruh yang signifikan terhadap distribusi oksigen terlarut. Hal ini, dikarenakan pada semua media uji diberikan pemasukan oksigen terlarut dengan bantuan aerator, sehingga oksigen terlarut tidak menjadi pemasalahan yang dapat mengganggu kelangsungan hidup hewan uji. Selain distribusi oksigen terlarut, penggunaan oksigen dalam wadah pemeliharaan dapat menjadi salah satu faktor yang mempengaruhi tingkat kelangsungan hidup. Rejeki et al. (2019) menjelaskan bahwa penggunaan oksigen yang meningkatnya dapat terjadi jika kandungan plankton melimpah (plankton bloom) serta meningkatnya kandungan bakteri dalam sistem karena adanya akumulasi limbah organik (feses, sisa pakan dalam air). Selama penelitian berlangsung, tidak ditemukan adanya kandungan planton yang melimpah (blooming plankton) pada semua wadah pemeliharaan yang dapat mengganggu kelangsungan hidup hewan uji.

Dame (2012) menjelaskan bahwa larva kerang bivalvia harus dapat beradaptasi dengan pergerakan massa air yang sama seperti dialami oleh kerang bivalvia dewasa, tetapi dengan pendekatan yang berbeda. Winanto (2004) menjelaskan bahwa masa transisi yang cukup kritis dalam kehidupan spat terjadi setelah spat dipindahkan di laut, yang dapat menyebabkan kematian (mortalitas) mencapai 98\%. Taufiq et al. (2010) menjelaskan bahwa spat sangat sensitif dan mudah stress, dengan melakukan pemindahan spat ke laut, kelangsungan hidup spat dipengaruhi oleh kondisi alam serta penambahan parameter-parameter kondisi lingkungan yang menunjang kehidupan spat yang sebelumnya tidak ada pada kondisi di lingkungan hatchery, salah satunya adalah pergerakan massa air. Namun dalam penelitian ini tidak dilanjukan sampai pemeliharaan spat di laut, sehingga tidak diketahui apakah uji pergerakan air memberi dampak terhadap 
kelangsungan hidup benih/spat yang dipindahkan dan dipelihara di laut.

\section{Pertumbuhan}

Hasil penelitian menunjukan perlakuan $600 \mathrm{ml} /$ menit memberikan hasil pertumbuhan mutlak yang paling tinggi dibandingkan dengan perlakuan yang lainnya pada kedua bagian, anterior-posterior dan dorsal-ventral, tetapihasil analisis ragam (ANOVA) menunjukan tidak adanya perbedaan yang nyata antar semua perlakuan. Galtsoff (1933) dalam Southgate dan Lucas (2008) menjelaskan bahwa pergerakan massa air yang kuat dapat meningkatkan laju pertumbuhan kerang $P$. maxima dan $P$. margaritifera. Namun pernyataan tersebut ditunjukan kepada kerang bivalvia dewasa pada umumnya, kerang bivalvia dewasa khususnya kerang mutiara $(P$. maxima), tidak berenang di kolom atau di permukaan air seperti pada stadia larvanya. Sehingga, pergerakan massa air sebagai penghantar pakan alami yang lebih merata pada wadah pemeliharaan untuk mendukung pertumbuhan larva kerang mutiara, tidak memberi pengaruh yang nyata terhadap pertumbuhannya.

Hasil laju pertumbuhan spesifik yang diperoleh menunjukan bahwa perlakuan 600 $\mathrm{ml} /$ menit memberikan laju pertumbuhan spesifik tertinggi dibandingkan dengan perlakuan lainnya pada bagian anteriorposterior dan dorsal-ventral, dengan lama pemeliharaan selama 40 hari. Hasil analisis ragam (ANOVA) menunjukan tidak ada perbedaan nyata terhadap laju pertumbuhan spesifik larva kerang mutiara (P. maxima) pada kecepatan aliran media pemeliharaan. Gosling (2015) menjelaskan bahwa pergerakan air tidak hanya menghantarkan pasokan makanan untuk kerang bivalvia, namun juga dapat merangsang bivalvia untuk makan dan meningkatkan laju filtrasi pada kerang bivalvia.

Selain pakan atau nutrisi yang diberikan, kondisi lingkungan dan parameter kualitas air juga memberi pengaruh terhadap pertumbuhan kerang mutiara. Berdasarkan hasil yang diperoleh, kualitas air dalam wadah pemeliharan tidak berbeda signifikan antar perlakuan dan masih dalam nilai batas yang mendukung pertumbuhan kerang mutiara. Hal tersebut disebabkan oleh adanya pengontrolan media hidup hewan uji untuk semua perlakuan setiap 4 hari sekali.

\section{Perkembangan Stadia}

Hewan uji yang digunakan berupa larva (P. maxima) stadia D-veliger yang berumur 24 jam setelah pemijahan, dengan ukuran rata-rata $90 \mu \mathrm{m} \times 60 \mu \mathrm{m}$. Menurut Ode (2010), larva mengalami perubahan stadia dari trochofor ke stadia D-veliger dalam waktu 18-20 jam, dengan ukuran $80 \mu \mathrm{m}-90 \mu \mathrm{m}$ dan akan berubah menjadi stadia umbo dalam beberapa hari.

Hasil penelitian menunjukan bahwa larva (P. maxima) hewan uji mencapai stadia umbo rata-rata pada semua perlakuan adalah 15 hari. Berdasarkan hasil kecepatan waktu metamorfosis dari stadia D-veliger sampai umbo yang dibutuhkan, menunjukan bahwa perlakuan $200 \mathrm{ml} /$ menit memberikan waktu tercepat dibandingkan dengan ketiga perlakuan lainnya, yaitu dengan perolehan waktu tempuh rata-rata 15 hari 2 jam, diikuti secara berturut turut oleh perlakuan $600 \mathrm{ml} /$ menit dengan perolehan kecepatan waktu metamorfosis ratarata 15 hari $10 \mathrm{jam}$, perlakuan $400 \mathrm{ml} / \mathrm{menit}$ memperoleh kecepatan waktu metamorfosis rata-rata 15 hari 12 jam, dan perlakuan kontrol memperoleh kecepatan waktu metamorfosis rata-rata 16 hari 20 jam.

Setelah stadia umbo larva akan mengalami metamorfosis menjadi stadia eyespot yang ditandai dengan adanya bintik hitam pada larva. Stadia eyespot pada hewan uji diperoleh dengan waktu rata-rata 4 hari untuk semua perlakuan dari stadia umbo. Menurut Hamzah (2015), stadia eyespot merupakan indikasi larva akan mulai menempel dan indikasi untuk mulai memasang kolektor pada wadah pemeliharaan. Berdasarkan hasil yang diperoleh dalam kecepatan waktu metamorfosis rata-rata perkembangan dari stadia umbo ke stadia eyespot menunjukan bahwa perlakuan kontrol memperoleh kecepatan waktu metamorfosis rata-rata tercepat dibandingkan ketiga perlakuan lainnya, dengan perolehan kecepatan waktu metamorfosis rata-rata 3 hari 20 jam dari stadia umbo ke stadia eyespot. Perlakuan 200 $\mathrm{ml} /$ menit memperoleh kecepatan waktu metamorfosis rata-rata 4 hari 22 jam, perlakuan $400 \mathrm{ml} /$ menit memperoleh kecepatan waktu metamorfosis rata-rata3 hari 22 jam dan perlakuan $600 \mathrm{ml} /$ menit memperoleh kecepatan waktu tempuh rata-rata 4 hari 14 jam.

Stadia pediveliger pada hewan uji mulai tampak pada hari ke-21 setelah pemijahan, 
dengan ditandai adanya kaki-kaki yang muncul pada larva. Berdasarkan hasil kecepatan waktu metamorfosis rata-rata perkembangan stadia dari stadia eyespot - pediveliger yang diperoleh, menunjukan bahwa perlakuan kontrol memberikan kecepatan waktu metamorfosis stadia pediveliger rata-rata tercepat dibandingkan perlakuan lainnya dengan perolehan waktu 4 hari 9 jam dan diikuti oleh perlakuan $200 \mathrm{ml} / \mathrm{menit}$ dengan perolehan kecepatan waktu metamorfosis ratarata 4 hari $20 \mathrm{jam}$; perlakuan $600 \mathrm{ml} /$ menit dengan perolehan kecepatan waktu metamorfosis rata-rata 5 hari 8 jam, dan terakhir perlakuan $400 \mathrm{ml} /$ menit dengan perolehan kecepatan waktu metamorfosis ratarata 5 hari 12 jam.

Setelah stadia pediveliger, hewan uji bermetamorfosis menjadi stadi spat pada hari ke-25 dengan ditandai adanya larva yang menempel pada kolektor. Larva yang menempel dikolektor diperiksa dengan menggunakan bantuan senter LED dan ditandai dengan bintik-bintik putih pada kolektor. Hal ini sesuai dengan Wardana et al. (2014) dan Hamzah et al. (2015) yang menjelaskan bahwa larva memasuki stadia spat pada kisaran umur 25 hari atau lebih. Hamzah (2015) menjelaskan bahwa larva stadia spat merupakan larva bersifat bentik, yaitu larva dalam keadaan menempel pada substrat/kolektor, sehingga makanan (phytoplankton) yang diperoleh sangat tergantung dari gerakan massa air.

\section{KESIMPULAN}

Kecepatan pergantian air sebesar 200 $\mathrm{ml} /$ menit sampai $600 \mathrm{ml} / \mathrm{menit}$ dapat meningkatkan perkembangan dan kelangsungan hidup larva kerang mutiara ( $P$. maxima) yang dipelihara pada skala laboratorium.

\section{REFERENSI}

Dame, R. F. 2012. Ecology of Marine Bivalves An Ecosystem Approach Second Edition. CRC Press.

Gosling, E. 2015. Marine Bivalve Molluscs Second Edition. Wiley Blackwell.

Hamzah, A. S., Hamzah, M., Hamzah, M. S. 2016. Perkembangan dan Kelangsungan Hidup Larva Kerang Mutiara (Pinctada maxima) pada Kondisi Suhu yang Berbeda. Media Akuatika, 1(3): 152-160.
Hamzah, M. S. 2015. Perubahan Tekanan Media Pemeliharaan Larva Kerang Mutiara (Pinctada maxima) Terhadap Daya Reaksi Enzim Protease dalam Memacu Pertumbuhan dan Sintasan. Jurnal Ilmu dan Teknologi Kelautan Tropis, 7(2): 655-669.

Indrayana, R., Yusuf, M., Rifai, A. 2014. Pengaruh arus permukaan terhadap sebaran kualitas air di perairan Gunuk Semarang. Jurnal Oseanografi, 4(3): 651659.

Kelabora, D. M., Sabariah. 2010. Tingkat pertumbuhan dan kelangsungan hidup larva ikan bawal air tawar Collosoma sp dengan laju debit air berbeda pada sistem resirkulasi. Jurnal Akuakultur Indonesia, 9(1): 56-60.

Ode, I. 2010. Pengamatan Pemijahan dan Perkembangan Larva Kerang Mutiara (Pinctada maxima) dalam Bak Terkontrol. Bimafika, 2: 86-89.

Rejeki, S., Aryati, R. W., Widowati, L. L. 2019. Pengantar Akuakultur. Undip Press. Semarang.

Septy, Suryaningsih, S.A., Abdul Syukur, 2018. Perbedaan berat (gram) bibit kerang mutiara (Pinctada maxima) antar warna cangkang di perairan Tekalok Lombok Timur NTB. Jurnal Biologi Tropis, 18(1): $\quad 34-44$. http://dx.doi.org/10.29303/jbt.v18i1.564

Southgate, P. C., Lucas, J. S. 2008. The pearl oyster. Elsevier. Amsterdam.

Sudewi., Supii, A. I., Wardana, I. K. 2016. Permasalahan Pada Pembenihan Kerang Mutiara (Pinctada maxima). Prosiding Forum Inovasi Teknologi Akuakultur, 1(1): 133-138.

Sujoko, A. 2010. Membenihkan Kerang Mutiara. Pustaka Insan Madani. Yogyakarta.

Taufiq, N., Rachmawati, D., Cullen, J., Yuwono. 2010. Aplikasi Isochrysis galbana dan Chaetoceros amami Serta Kombinasinya terhadap Pertumbuhan dan Kelulushidupan Veliger-Spat Tiram Mutiara (Pinctada maxima). Indonesian Journal of marine Science, 15(3): 119125.

https://doi.org/10.14710/ik.ijms.15.3.119 $-125$ 
Tomatala, P. 2014. Efektifitas Penggunaan Bingkai Jaring Pada Penjarangan Benih Kerang Mutiara, Pinctada maxima. eJurnal Budidaya Perairan, 2(1): 1-6. https://doi.org/10.35800/bdp.2.1.2014.37 86

Wardana, I. K., Sudewi, Muzaki, A., Moria, S. B. 2014. Profil Benih Kerang Mutiara (Pinctada maxima) Dari Hasil Pemijahan yang Terkontrol. Jurnal Oseanologi Indonesia. 1(1): 6-11.

Winanto, T. 2004. Memproduksi Benih Kerang Mutiara. Penebar Swadaya. Jakarta.

Zonneveld, N. E., Husiman, A., Bond, J. H. 1991. Prinsip-prinsip Budidaya ikan. Gramedia Pustaka Utama. Jakarta. 